\title{
Assessment of 4-H Range Management Programs in the United States
}

\section{By Kevin P. Allen, R. Dwayne Elmore, John R. Weir, and Sarah R. Lancaster}

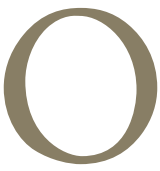

ver the past several decades the public has become increasingly concerned about the uses and management of rangelands. While rangelands are important for open space, energy, grazing, and minerals, they also need to be considered for aesthetic value, wildlife habitat, and recreation value. ${ }^{1}$ Increasingly, rural land fragmentation for residential development is occurring in many regions of the country, particularly in the western United States. Exurban development is now the fastest-growing form of land use in the United States, covering nearly $25 \%$ of the area in the lower 48 states. This change is occurring most rapidly in the Southwest and in the Mountain West and typically involves the conversion of rangelands to residential property. ${ }^{2}$ The development of these open spaces into dispersed rural residences adversely affects wildlife habitat and migration patterns, the amount of scenic lands, access to public lands, and the rural sense of community. ${ }^{3}$ Public acceptance has become increasingly critical to the success of rangeland management as debate intensifies worldwide over ecosystem protection and sustainable development. ${ }^{4}$ Successful managers of federal rangelands in the next century will have to implement politically supportable policies that address both forage and nonforage values. ${ }^{5}$ To do so will require an understanding of beliefs and attitudes across a wider spectrum of American society than the traditional range clientele.

We propose the $4-\mathrm{H}$ program as one mechanism that should be used to educate youth regarding the importance of rangelands and issues facing them. 4- $\mathrm{H}$ is the youth development program administered by the National Institute of Food and Agriculture of the United States Department of Agriculture (USDA). This program serves over 6 million youth in the United States and is designed to develop citizenship, leadership, and life skills through experiential learning programs developed using the research base of the land-grant university system. ${ }^{6}$ With direct connection to the cutting-edge research of the nation's land-grant institutions, $4-\mathrm{H}$ is strategically positioned to strengthen the United States' global competitiveness and leadership in science, engineering, and technology. ${ }^{1}$ While $4-\mathrm{H}$ is typically thought of as an agriculturally focused organization, the program broadly focuses on citizenship; healthy living; and science, engineering, and technology.

As youth become the voters and leaders of the future, it is important to provide them with educational opportunities through which they gain research-based knowledge and develop skills needed to make important, informed decisions regarding rangelands. Based on the importance of rangelands to society and the potential impact that $4-\mathrm{H}$ can have as an educational tool, we sought to assess the level at which current $4-\mathrm{H}$ programs are educating youth on the issues facing rangelands in order to make recommendations for future direction.

\section{Methods}

To assess 4-H rangelands and range management programs in the United States, we developed and administered a questionnaire to collect baseline data related to this program area. The questionnaire and research design generally followed the Dillman ${ }^{7}$ method, with approval of the Oklahoma State University Institutional Review Board (IRB\# AG0839). Sixteen questions were designed to collect information concerning the current level of participation and perceived interest in 4- $\mathrm{H}$ rangelands and range management programs, while five questions were used to gather demographic information.

A cover letter explaining the research goal, assessment survey, and a prepaid envelope were mailed to the State 4-H Director (or equivalent) in all 50 states. Directors were encouraged to forward the survey, when appropriate, to a more informed or specialized staff person to complete the questionnaire. A follow-up letter and questionnaire were sent 6 weeks after the initial letter to all nonrespondents. 
Table 1. Response by those states that offer 4-H range programs regarding program effectiveness and importance and personal confidence in delivering 4-H range management programs. All questions used a Likert scale of 1 to $5^{9}$

\begin{tabular}{|l|c|c|c|}
\hline $\begin{array}{l}\text { Perceived effectiveness of } 4-\mathrm{H} \\
\text { range programs achieving their } \\
\text { desired objectives }\end{array}$ & 3.09 & 1.22 & 0.37 \\
\hline $\begin{array}{l}\text { Perceived importance of range } \\
\text { management to them personally }\end{array}$ & 3.45 & 1.21 & 0.37 \\
\hline $\begin{array}{l}\text { Perceived importance of range } \\
\text { management to their state }\end{array}$ & 3.91 & 0.94 & 0.28 \\
\hline $\begin{array}{l}\text { Perceived importance of range } \\
\text { management to youth in their } \\
\text { state }\end{array}$ & 2.73 & 1.10 & 0.33 \\
\hline $\begin{array}{l}\text { Personal confidence in delivering } \\
4-\mathrm{H} \text { range management pro- } \\
\text { grams }\end{array}$ & 3.36 & 1.21 & 0.36 \\
\hline
\end{tabular}

The information gained from this survey was used by professionals in natural resources and $4-\mathrm{H}$ to assess participation in this program area, to compile a current list of educational $4-\mathrm{H}$ project materials being used, and to determine whether there was need or interest in additional materials for $4-\mathrm{H}$ members and volunteers. Percentages, means, and standard errors (SE) were used to examine responses.

\section{Results}

Fifty usable surveys were returned, resulting in a response rate of $100 \%$. Respondents were asked whether their state offered a 4-H rangelands and/or range management program, and 12 states (24\%) indicated that they currently offer a 4-H program in this area. Of the states that offer a range management program, At Home on the Range, ${ }^{8}$ available through Montana 4- $\mathrm{H}$, was listed as the educational material most often used (36\%). Several states indicated that they utilize locally developed educational materials in this program area. Forty-two percent of the states that offer a $4-\mathrm{H}$ range management program provided hard copies of educational materials, while $58 \%$ indicated materials were made available to members in both hard copy and via the Internet.

Those who indicated that their state offers $4-\mathrm{H}$ range management programs were asked to respond to a series of questions regarding the effectiveness and importance of these programs (Table 1). While 12 states indicated that they offered a 4-H range management program, only 11 responded to this set of questions. Combined results indicate that these $4-\mathrm{H}$ programs were perceived as being somewhat effective in achieving the desired objectives. Respondents perceive that range management is important to them personally, that range management is important to their state, and that range management is somewhat important to youth in their state. In general, respondents indicate they are confident in delivering 4- $\mathrm{H}$ range management programs.

The next series of questions were related to interest in range management curriculum: who should develop these materials and how best to access these materials. Five states indicated that they currently have plans to develop new materials in the area of rangelands or range management, while 19 respondents expressed interest in $4-\mathrm{H}$ range management curriculum. If new materials were developed, $12 \%$ preferred a national curriculum, $24 \%$ preferred a statespecific curriculum, and $28 \%$ preferred a combination of both national and state curricula. Most (62\%) respondents indicated that a Web site with age-appropriate $4-\mathrm{H}$ range management materials would be useful. Those not interested in curriculum indicated lack of interest from clientele $(36 \%)$, other (26\%), lack of funds (14\%), lack of time (12\%), lack of materials (10\%), lack of knowledge (8\%), and lack of personal interest (2\%) as reasons for their lack of interest in curriculum.

Next, we wanted to know who provides assistance to range projects in each state. Eleven states $(22 \%)$ indicated that they have a State Extension Range Specialist, while four states (8\%) indicated that they have both State and District Extension Range Specialists. Of the 15 states with an extension range specialist, 7 states (47\%) responded that this position has $4-\mathrm{H}$ program responsibilities. Those states without any extension range specialists contact National Resources Conservation Service (40\%) and the Farm Service Agency (17\%), most often regarding their range management needs.

Nineteen states (38\%) indicated that they are aware that there is a National Range Judging Contest. Seven states (14\%) indicated that they conduct a state level 4-H contest, and five states $(10 \%)$ responded that they send a state $4-\mathrm{H}$ team to the National Contest on a regular basis.

Finally, we asked whether professional development opportunities would be useful in increasing $4-\mathrm{H}$ programming efforts in range management, and $32 \%$ indicated that it would be useful. Respondents indicated that they acquire professional development from the National Association of Extension 4-H Agents (60\%), state in-service opportunities (48\%), National Association of County Agricultural Agents (14\%), other (12\%), Association of Natural Resource Extension Professionals (6\%), and National Extension Association of Family and Consumer Science (4\%).

\section{Discussion}

We found that 12 states currently offer a $4-\mathrm{H}$ rangeland or range management program, and all of these are western states that are dominated by rangelands. This leaves six western states with large rangeland areas, as well all eastern states with substantial rangeland, that have no $4-\mathrm{H}$ range 


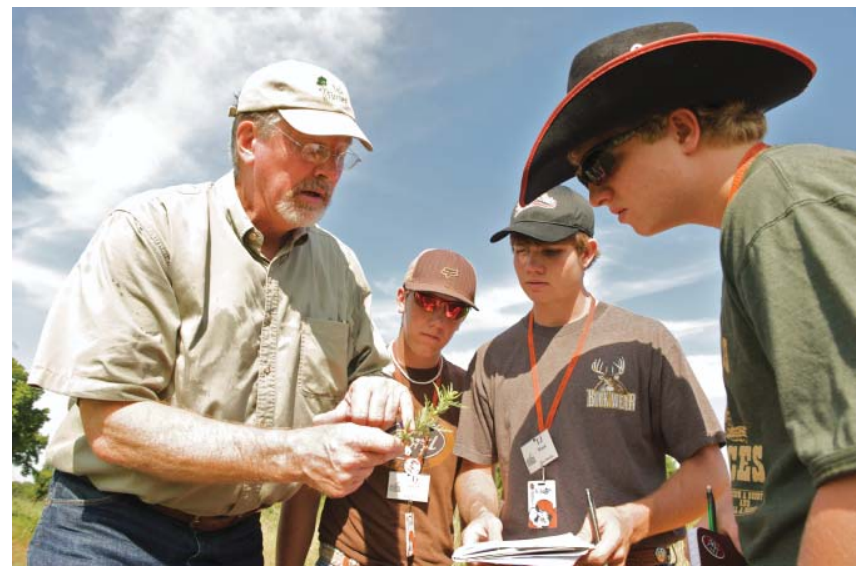

Extension Range Specialist Dr Terry Bidwell helps 4-H members to identify common range plants.

program. With national 4-H enrollment of nearly 6 million members, ${ }^{10}$ enrollment in $4-\mathrm{H}$ rangeland or range management programs nationwide is just over $1 \%$. It is possible that the current $4-\mathrm{H}$ range management projects do not match the interests of today's youth or that the programs may not be promoted adequately. However, there is an interest in 4- $\mathrm{H}$ range curriculum beyond the western United States. We found six eastern states desiring information related to range programs.

States offering a $4-\mathrm{H}$ rangeland and/or range management projects listed At Home on the Range, available through Montana $4-\mathrm{H}$, as the most commonly used educational material. This program is the first national curriculum for rangeland that meets the National Science Education Standards. ${ }^{1}$ The majority of respondents also indicated that they utilize locally developed educational materials in this project area. The fact that most programs made $4-\mathrm{H}$ range material available to members in both hard copy and via the Internet (62\%) suggests that Web-based information may be the best platform for reaching clientele.

Generally, states offering 4-H range programs believed that the curriculum was effective and that range management was important to the state. However, they indicated range and range management was only somewhat important to youth. We suspect that this reflects the general trend of youth being disconnected with nature. For the first time in history, the bond between children and nature has been broken. Youth prefer to play inside where there are electrical outlets instead of outdoors where the birds sing. Computers, TVs, and video games contribute to what Louv titled "nature-deficit disorder," as do heightened parental fears and classrooms increasingly removed from nature. ${ }^{11}$ Visits to US National Parks have decreased by over 20\% since 1988-it is the first persistent downward trend in US park history. Most of the decline in visits (98\%) is attributed to four variables: 1) time spent watching movies, 2) time spent surfing the Internet, 3) time spent playing video games, and 4) oil prices. These trends might be early signs

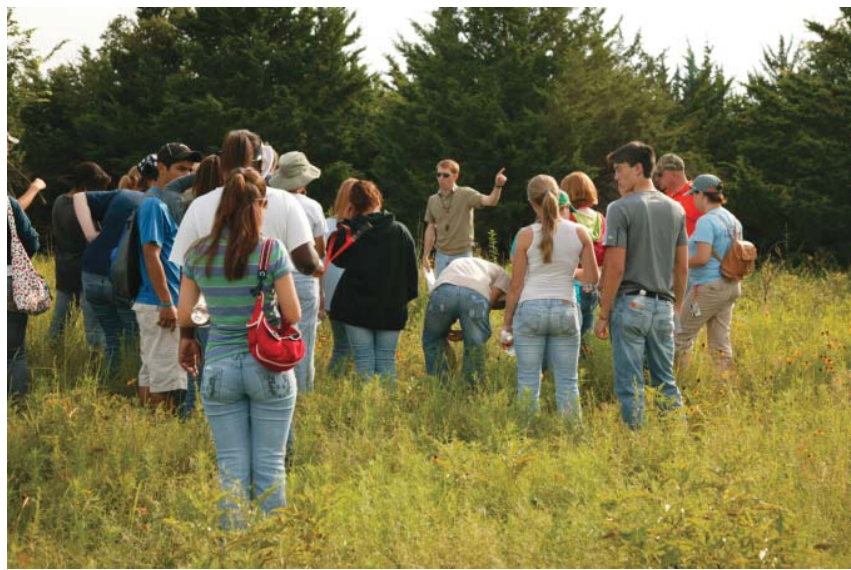

Intercity youth participate in a "Range Day." By using hands-on tools such as GPS technology, prescribed fire, and research dogs, range science can be both engaging and relevant to youth.

of a shift away from outdoor recreation and appreciation of nature. ${ }^{12}$ It has been suggested that this growing disconnect with nature has serious implications for future stewardship of public lands and that rangeland programs could help bridge the gap caused by this disconnect. If youth experience nature, they have a better chance of understanding the societal values that rangelands provide. ${ }^{1} \mathrm{We}$ are just starting to recognize the effects of technologies and two wage-earning parents on the willingness, or unwillingness, of the children of these parents to explore the outdoors. These parents want to protect their children from elements of their environment, but they have created an entire generation of youth who are not connected to the land..$^{13}$ Teaching youth about the natural environment provides real-world perspectives for learning. As youth participate in hands-on learning about nature, their knowledge and awareness of the environment increases. This also encourages inquiry and investigation, fostering the development of critical thinking, problem solving, and effective decision making. Environmentally literate students become citizens who are able to weigh various sides of an environmental issue and make responsible decisions as individuals and as members of their communities. ${ }^{11}$ As the amount of open space continues to disappear, this will only decrease the opportunities youth have to learn outdoors.

Of the 50 states, 19 indicated an interest in a 4-H range curriculum. An unexpected response was that six of these were not western states. The most common reason given for why a state might not be interested in $4-\mathrm{H}$ range curriculum was lack of interest from clientele, but the respondents that indicated lack of interest from clientele were eastern states that have few remaining rangelands due to conversion to introduced grasses and fire suppression. As rangelands diminish and youth are no longer exposed to this important natural resource, this probably creates a greater disconnect with rangelands and their importance. Additionally, consumptive uses of rangelands such as grazing may find limited public support. If youth do not have a grasp of the 
importance of natural resources and what rangeland ecosystems can provide, as adults they may not be concerned with issues such as protecting land from being fragmented by urbanization. ${ }^{1}$ Childhood participation with nature (e.g., camping, hiking, and outdoor education) has a significant, positive effect on both adult environmental attitudes and behaviors. People who participated in "wild" nature activities as children were more likely to have proenvironmental attitudes and behaviors as adults. ${ }^{14}$

From the survey results we found that several western states do not have either a state or district extension range specialist, despite the importance of rangelands in these areas. Only half of the states that did have these positions indicated that the position had $4-\mathrm{H}$ responsibilities. Thus, the lack of youth enrolled in range management projects is not surprising. Additionally, few $4-\mathrm{H}$ programs regularly participated in the National Range Judging Contest or a state level contest in range judging. In reviewing past registrations of teams who have attended the national contest, these findings are consistent with survey results. ${ }^{15}$ It is worth mentioning that several states regularly send more than one 4-H team from their state to compete at this event. However, those states that do conduct $4-\mathrm{H}$ state contests or attend the national contest had a state or district extension range specialist with $4-\mathrm{H}$ program responsibilities. This would seem to indicate that these individuals play an important role in enhancing youth interest in range management. Thus, having either state or district range specialists that have youth education responsibilities is critical to engaging youth regarding the value of rangelands and open spaces. This should be a target goal for all states with range resources.

\section{Implications}

Open spaces such as rangelands are rapidly disappearing due to fragmentation caused by suburban and "ranchette" developments. Concern has been raised by rural citizens and conservation groups regarding the loss of agricultural production and biological diversity, and by urban interests that mourn the loss of open space and recreation opportunity. ${ }^{2}$ Significant effort needs to be expended to prepare a well-informed citizenry capable of making educated decisions when it comes to the complex issues facing rangelands.

The 4-H Youth Development Program, with nearly 6 million members in the United States, and proven to have positive effects on youth that result in young adults who are prepared to contribute and lead at the local, state, national, or international level, is an appropriate venue to begin educating youth on the value of rangelands and open spaces.

We recommend that states with large amounts of rangeland address the lack of programming offered in this area; only six western states and no eastern states with substantial rangelands have a $4-\mathrm{H}$ range program. In addition, employing an extension range specialist with $4-\mathrm{H}$ responsibilities in those states with extensive range resources may be the first step to getting more youth involved in educational offerings in range management.

Results of this study will be shared with those states planning to develop new educational curricula to provide them a better understanding of the needs that $4-\mathrm{H}$ programs have in rangelands and range management projects. To better serve the 4-H program, linking with Rangelands eXtension may provide Web-based 4-H curriculum materials. eXtension is a digital space where university content providers gather to produce new educational and information resources on a variety of topics. Because it is available via the Internet to students, researchers, clinicians, professors, as well as the general public, eXtension helps solve real-life problems in real time. One approach would be to create a curriculum development task force composed of extension range specialists and $4-\mathrm{H}$ youth development specialists who would have responsibility for reviewing submitted materials. This team would make certain that the information presented is technically accurate while ensuring that the materials developed are developmentally and age appropriate before posting on eXtension. This would also allow for the creation of state or regional materials while letting others interested in youth range management programs gain access to these materials.

\section{Acknowledgments}

Funding was provided by the Oklahoma Cooperative Extension Service. The authors wish to thank Dr Karen Hickman for her assistance in reviewing this paper and providing critical feedback.

\section{References}

1. Gordon, K. 2007. New roles for rangelands and grasslands. Rangelands 29(3):53-55.

2. Resnik, J., G. Wallace, M. Brunson, and J. Mitchell. 2006. Open space, working places. Rangelands 28(5):4-9.

3. McLeod, D., J. Woirhaye, C. Kruse, and D. Menkhaus. 1998. Private open space and public concerns. Applied Economic Perspectives and Policy 20(2):644-653.

4. Shindler, B. A., And M. W. Brunson. 2004. Social acceptability in forest and range management. In: M. J. Manfredo, J. Vaske, B. L. Bruyere, D. R. Field, and P. J. Brown [EDs.]. Society and natural resources: a summary of knowledge. Columbia, MO, USA: Modern Litho. p. 147-157.

5. Brunson, M. W., And B. S. Steel. 1996. Sources of variation in attitudes and beliefs about federal rangeland management. Journal of Range Management 49:69-75.

6. National 4-H Headquarters. 2009. About 4-H. Available at: http://www.national4-hheadquarters.gov/about/4h_about. htm. Accessed 25 February 2009.

7. Dillman, D. A. 2000. Mail and internet surveys: the tailored design method. 2nd ed. New York, NY, USA: John Wiley and Sons. 464 p.

8. Coley, M., and K. A. Astroth. 2005. At home on the range: level 1. Bozeman, MT, USA: Montana State University. 75 p.

9. Likert, R. 1932. A technique for the measurement of attitudes. Archives of Psychology 140:1-55. 
10. Research, Education \& Economics Information System. 2009. Available at: http://www.reeis.usda.gov/discoverer/ viewer?cn=cf_a1328\&wskdel=9\&nlsl=en-us\&wbk=3-0_4-H_ TOT_ENROLL_DUP_EXC\&pg $=1 \&_{-}$act $=$apply $\&$ _ poqpv $=$ off $\&$ _podat $=$ on $\&$ _polws $=$ off $\&$ _popim $=$ on $\&$ _ pocht $=$ off \&_podri $=$ on \&_poexp=on\&_porrq $=$ on\&_poset $=$ reset. Accessed 21 February 2009.

11. Louv, R. 2006. Last child in the woods. Chapel Hill, NC, USA: Algonquin Books of Chapel Hill. 334 p.

12. Pergams, O. R. W., and P. A. Zaradic. 2006. Is love of nature in the U.S. becoming love of electronic media? 16-year downtrend in national park visits explained by watching movies, playing video games, internet use, and oil prices. Journal of Environmental Management 80:387-393.

13. McGuire, S. R. 2008. Speaking with people in our profession: an interview with Dr. Mark Brunson. Rangelands 30(1):27-28.
14. Wells, N. M., And K. S. Lekies. 2006. Nature and the life course: pathways from childhood nature experiences to adult environmentalism. Children, Youth and Environments 16(1): $1-24$.

15. Landjudging.com. 2008. Final news release for 2008. Available at: http://www.landjudging.com/includes/2008_land_ news.pdf. Accessed 24 February 2009.

Authors are Assistant Professor and Extension Youth Specialist, Natural Resource Ecology and Management Dept (NREM), kevin.allen@okstate.edu (Allen), Assistant Professor and Extension Wildlife Specialist, NREM (Elmore), Research Associate, NREM (Weir), and Assistant Professor, Plant and Soil Science Dept (Lancaster), Oklahoma State University, Stillwater, OK 74078, USA. 